\title{
KONTRIBUSI PELAYANAN TERPADU TERHADAP PENDAPATAN ASLI DAERAH KOTA PALOPO
}

\author{
BURHANUDDIN, MUSTAFA MUHANI, SALJU SANUDDIN
}

\begin{abstract}
ABSTRAK
Penilaian untuk mengetahui pengaruh/kontribusi penerimaan Kantor Pelayanan Terpadu Kota Palopo terhadap PAD kota palopo yakni :

$a=15,906$ menunjukkan bahwa tanpa adanya variabel $(X)$ pendapatan KPT,maka besarnya PAD Kota Palopo sebesar 15,906 milyar. $b=2,068$ pengaruh pendapatan Kantor pelayanan Terpadu terhadap PAD Kota Palopo sebesar 2,068 milyar pertahun.

Penelitian ini bertujuan untuk mengetahui yang ingin dicapai sehubungan dengan penulisan penelitian skripsi ini adalah : untuk mengetahui seberapa besar kontribusi yang diberikan oleh Kantor Pelayanan Terpadu Terhadap Pendapatan Asli Daerah Kota Palopo.

Berdasarkan hasil penelitian untuk mengetahui pengaruh/kontribusi penerimaan Kantor Pelayanan Terpadu Kota Palopo,maka dapat dilihat dari pengolahan data melalui program SPSS 16.00 (terlampir),yang diperoleh persamaan sebagai berikut $: Y=a+b X \quad=15,906+2,068 X$

Kesimpulannya Bahwa pendapatan KPT tidak signifikan terhadap peningkatan Pendapatan Asli Daerah Kota Palopo.dan Didapatkan dari hasil nilai determinasi menunjukkan bahwa pengaruh KPT terhadap naik/turunnya PAD kota palopo sebesar $37 \%$ sedangkan pengaruh variabel lain sebesar $63 \%$.
\end{abstract}

Kata kunci: Pelayanan terpadu, Pendapatan Asli Daerah 


\section{Pendahuluan}

\section{Latar Belakang}

Birokrasi perizinan merupakan salah satu permasalahan yang menjadi hambatan perkembangan usaha di Indonesia.dari beberapa hasil studi yang telah dilakukan oleh berbagai pihak menunjukkan bahwa proses perizinan tidak memiliki kejelasan prosedur,mekanisme yang berbelit-belit,tidak transparan,waktu yang tidak pasti,dan biaya yang tinggi harus dikeluarkan masyarakat terutama berkaitan dengan biaya-biaya yang tidak resmi.Menyadari akan hasil studi tersebut,maka pemerintah daerah kota palopo sangat responsive dan akomodatif untuk melakukan perubahan pelayanan publik dibidang perizinan melalui Permendagri Nomor 24 Tahun 2006 tentang Pelayanan Terpadu Satu Pintu,atas dasar tersebut komitmen pemerintah kota palopo untuk melakukan penyederhanaan prosedur perizinan dengan membentuk lembaga pelayanan terpadu satu pintu dengan nama Kantor Pelayanan Terpadu Satu Pintu (KPTSP).

Kantor Pelayanan Terpadu Satu Pintu sebagai satuan kerja perangkat daerah yang dibentuk dengan Perda Kota Palopo Nomor 08 Tahun 2007 dan Peraturan Walikota Palopo Nomor 27 Tahun 2007 dengan kewenangan pelayanan Perizinan dan secara resmi dioperasionalkan/dilaunchingkan oleh Gubernur Sulawesi Selatan pada tanggal 2 juli 2007. Hanya berselang setahun lebih karena implikasi lahirnya PP Nomor 41 Tahun 2007 tentang perangkat daerah sehingga dilakukan penataan perangkat daerah dilingkup pemerintahan kota palopo.Maka KPTSP berubah nama kelembagaan menjadi Kantor Pelayanan Terpadu (KPT) dengan Perda kota palopo Nomor 4 Tahun 2008 dan peraturan Walikota Palopo Nomor 47 Tahun 2009 dengan Kewenangan Penyelenggaraan Pelayanan Perizinan pada KPT.

Seperti halnya kota-kota di Indonesia pada umumnya,Kota palopo memiliki visi dan misi yang merupakan gambaran umum tentang tujuan dan sasaran yang ingin dicapai pada masa yang akan datang.

Dari uraian-uraian latar belakang diatas,diketahui bahwa begitu banyak perizinan yang dilakukan di KPT Kota Palopo sehingga KPT memberikan banyak manfaat bagi Pemerintah Kota Palopo khususnya terhadap Pendapatan Asli Daerah Kota Palopo.oleh karena itu,penulis merasa tertarik untuk mengajukan penelitian dengan judul "Kontribusi Kantor Pelayanan Terpadu Terhadap Pendapatan Asli Daerah Kota Palopo". Masalah Penelitian ini adalah Seberapa Besar Kontribusi Kantor Pelayanan Terpadu Terhadap Pendapatan Asli Daerah Kota Palopo?. Tujuan Penelitian ini adalah untuk mengetahui seberapa besar kontribusi yang diberikan oleh Kantor Pelayanan Terpadu Terhadap Pendapatan Asli Daerah Kota Palopo 


\section{Metode Penelitian}

Tempat dan Waktu Penelitian

Lokasi penelitian dalam penulisan proposal skripsi ini adalah Kantor Pelayanan Terpadu Kota Palopo.Sedangkan waktu penelitian dimulai dari bulan februari tahun 2012 sampai dengan bulan April tahun 2012.

Metode Pengumpulan Data

Metode pengumbulan data yang digunakan dalam penulisan ini yaitu: (a) Penelitian Lapangan ( field research ); Untuk pengumpulan data yang diperlukan,penulis mengadakan peninjauan langsung pada kantor Pelayanan Terpadu Kota Palopo. (b) Penelitian Kepustakaan ( library research ); Dalam penelitian,penulis mengadakan penelitian kepustakaan dengan mengutip berbagai sumber bacaan yang erat kaitannya dengan penulis skripsi ini berupa literature,bukubuku dan dokumen-dokumen yang membahas tentang masalah perizinan dan non perizinan di Kantor Pelayanan Terpadu Kota Palopo.

Jenis dan Sumber Data

(a) Data Primer,yaitu data yang diperoleh langsung pada kantor Pelayanan Terpadu Kota Palopo,baik berupa wawancara pada pihak Kantor Pelayanan Terpadu Kota Palopo maupun dengan penelitian laporan dokumendokumen serta berkas-berkas mengenai data yang dibutuhkan.

(b) Data sekunder, yaitu data yang sudah diolah yang sumbernya berasal dari Kantor Pelayanan Terpadu kota Palopo yang diteliti maupun dari pihak lain yang memiliki informasi mengenai masalah yang diteliti.

Metode Analisis Data

Dalam penulisan skripsi ini,metode yang digunakan oleh penulis adalah metode analisis regresi sederhana dengan formulasi sebagai berikut :

$$
\mathrm{Y}=\mathrm{a}+\mathrm{bX}
$$

Dimana :

$\mathrm{Y}=$ Pendapatan Asli Daerah (PAD)

$\mathrm{X}=$ Pendapatan melalui Kantor Pelayanan Terpadu (perizinan)

$\mathrm{a}=$ Konstanta

$\mathrm{b}=$ Parameter Variabel X

\section{Hasil Penelitian Dan Pembahasan}

Deskripsi Hasil Penelitian

Beberapa penyederhanaan yang dilakukan melalui system Pelayanan Satu Pintu,yaitu : 
1) Pelayanan atas permohonan perizinan dan non perizinan dilakukan oleh perangkat daerah Penyelenggara Pelayanan Terpadu Satu Pintu ( PPTSP ) yaitu perangkat pemerintah daerah yang memiliki tugas pokok dan fungsi mengelola semua bentuk pelayanan perizinan dan non perizinan di daerah dengan system satu pintu.

2) Percepatan waktu proses penyelesaian pelayanan tidak melebihi standar waktu yang telah ditetapkan dalam peraturan daerah.

3) Kepastian biaya pelayanan tidak melebihi dari ketentuan yang telah ditetapkan dalam peraturan daerah.

4) Kejelasan prosedur pelayanan dapat ditelusuri dan diketahui setiap tahapan proses pemberian perizinan dan non perizinan sesuai dengan urutan prosedurnya.

5) Mengurangi berkas kelengkapan permohonan perizinan yang sama untuk dua atau lebih permohonan perizinan.

6) Pembebasan biaya perizinan bagi Usaha Mikro Kecil Menengah (UMKM) yang ingin memulai usaha baru sesuai dengan peraturan yang berlaku.

7) Pemberian hak kepada masyarakat untuk memperoleh informasi dalam kaitannya dengan penyelenggaraan pelayanan.

Perbaikan dalam aspek kelembagaan,yaitu :

1) Aspek Regulatif

Dalam hal ini,system pelayanan satu pintu mengandung implementasi yang berfokus pada desentralisasi dan mendukung otonomi daerah.

2) Aspek Koordinatif

Untuk menghindari tumpang tindih kelembagaan.

3) Aspek Sumber Daya Manusia

Berdasarkan aturan yang ada,bahwa pegawai yang ditugaskan PPTSP diutamakan yang mempunyai kompotensi dibidangnya.

4) Aspek Transparansi/partisipasi masyarakat

Tata cara pengaduan yang dilakukan secara jelas melalui berbagai media yang mudah diakses dan diketahui oleh masyarakat.

Pembahasan

Untuk mengetahui jumlah pendapatan yang bersumber dari kantor Pelayanan Terpadu Kota Palopo,maka dapat dilihat seperti pada table berikut ini : 


\begin{tabular}{|c|c|c|c|}
\hline Tahun & $\begin{array}{c}\text { Jumlah } \\
\text { Pendapatan }\end{array}$ & Perkembangan & Prosentase \\
\hline 2007 & 788.120 .000 & & \\
2008 & 2.420 .535 .000 & 1.632 .415 .000 & 207 \\
2009 & 3.707 .210 .000 & 1.286 .675 .000 & 53 \\
2010 & 3.039 .390 .000 & 667.820 .000 & 18 \\
2011 & 2.638 .445 .000 & 400.945 .000 & 13 \\
\hline Jumlah & 12.659 .055 .000 & & \\
\hline Rata-rata & 2.531 .810 .000 & & \\
\hline
\end{tabular}

Pada tersebut diatas menunjukkan bahwa pada tahun 2007 jumlah pendapatan Kantor Pelayanan Terpadu Kota Palopo sebesar Rp.788.120.000 pada tahun 2008 dimana jumlah pendapatan Kantor Pelayanan Terpadu Kota Palopo mencapai Rp.2.420.535.000 kemudian pada tahun 2009 mengalami peningkatan menjadi Rp.3.707.210.000 atau naik sebesar 53\%. Namun pada tahun 2010,pendapatan Kantor Pelayanan Terpadu Kota Palopo mengalami sedikit penurunan menjadi Rp.3.039.390.000 dan pada tahun 2011 turun 13\% menjadi Rp.2.638.445.000

Adapun untuk mengetahui perkembangan Pendapatan Asli Daerah (PAD) yang dilakukan dikantor Pelayanan Terpadu Kota Palopo,maka dapat diketahui dengan melihat perkembangan pendapatan dari tahun 2007-2011.untuk lebih jelasnya dapat dilihat pada table berikut :

Perkembangan Pendapatan Asli Daerah Kota Palopo

\begin{tabular}{|c|c|c|c|}
\hline Tahun & $\begin{array}{c}\text { Jumlah } \\
\text { Pendapatan }\end{array}$ & Perkembangan & Prosentase \\
\hline 2007 & 15.759 .000 .000 & & \\
2008 & 16.902 .000 .000 & 1.323 .000 .000 & 8,49 \\
2009 & 17.790 .000 .000 & 888.000 .000 & 5,25 \\
2010 & 26.461 .000 .000 & 8.671 .000 .000 & 48,74 \\
2011 & 29.000 .000 .000 & 2.539 .000 .000 & 9,6 \\
\hline Jumlah & 105.732 .000 .000 & & \\
\hline Rata-rata & 21.146 .400 .000 & & \\
\hline
\end{tabular}

Dengan melihat tabel diatas maka dapat dijelaskan bahwa,pada tahun 2007 jumlah Pendapatan Asli Daerah (PAD) Kota Palopo adalah Rp.15.579.000.000 kemudian pada tahun 2008 mengalami peningkatan Yakni Rp.16.902.000.000 pada tahun 2009 mengalami peningkatan yakni Rp.17.790.000.000 pada tahun 2010,Pendapata Asli Daerah (PAD) mencapai Rp.26.461.000.000 mengalami kenaikan yang cukup besar yakni 48,74\% dan terakhir pada tahun 2011 mengalami peningkatan yakni Rp.29.000.000.000 atau mengalami peningkatan sebesar 9,6\%.jadi kalau dirata-ratakan Pendapatan Asli Daerah (PAD) Kota Palopo setiap tahunnya mencapai Rp.21.146.400.000. 
Sedangkan untuk mengetahui pengaruh/kontribusi penerimaan Kantor Pelayanan Terpadu Kota Palopo,maka dapat dilihat dari pengolahan data melalui program SPSS 16.00 (terlampir),yang diperoleh persamaan sebagai berikut :

$$
\begin{aligned}
\mathrm{Y} & =\mathrm{a}+\mathrm{bX} \\
& =15,906+2,068 \mathrm{X}
\end{aligned}
$$

$\mathrm{a}=15,906$ menunjukkan bahwa tanpa adanya variabel $(\mathrm{X})$ pendapatan KPT,maka besarnya PAD Kota Palopo sebesar 15,906 milyar.

$\mathrm{b}=2,068$ pengaruh pendapatan Kantor pelayanan Terpadu terhadap PAD Kota Palopo sebesar 2,068 milyar pertahun.

Selanjutnya dari hasil pengolahan data melalui program SPSS 16.00

1.Nilai Koefisien Korelasi $(\mathrm{R})=0,14 \Rightarrow$ menunjukkan bahwa terdapat hubungan yang lemah antara KPT dengan PAD Kota Palopo yakni kurang signifikan.

2.Nilai Determinasi $\left(R^{2}\right)=0,37 \Rightarrow$ menunjukkan bahwa pengaruh KPT terhadap naik turunnya PAD Kota Palopo sebesar 37\%.

\section{Penutup}

Kesimpulan penelitian ini adalah: (a) Bahwa pendapatan KPT tidak signifikan terhadap peningkatan Pendapatan Asli Daerah Kota Palopo. (b) Didapatkan dari hasil nilai determinasi menunjukkan bahwa pengaruh KPT terhadap naik/turunnya PAD kota palopo sebesar 37\% sedangkan pengaruh variabel lain sebesar 63\%. Adapun saran dalam penelitian ini adalah: (a) Agar Pendapatan Asli Daerah (PAD)terutama yang bersumber dari perizinan dan non perizinan di Kantor Pelayanan Terpadu harus ditingkatkan dan dipacu terus dalam pelaksanaan otonomi daerah. (b) Kepada pihak pemerintah agar berupaya untuk lebih meningkatkan keahlian aparatnya dalam pengelolaan sumber-sumber penerimaan di Kantor Pelayanan Terpadu,sehingga pendapatannya dapat lebih ditingkatkan dan secara positif dapat pula ditingkatkan peranannya dalam menunjang pembangunan daerah.

\section{Daftar Pustaka}

Badudu,sultan.2001.Kamus Umum Bahasa Indonesia.jakarta: Pustaka Sinar Harapan

Guritno,T. 1992. Kamus Ekonomi. Yogyakarta: Gadjah Mada University Press.

Ibrahim, R . 1997 . Prospek BUMN dan Kepentingan Umum. Bandung: PT Citra Aditya Bakti.

Kepmenpan No. 63/KEP/M.PAN/7/2003

Kotler, Philip. 1997. Manajemen Pemasaran. Jakarta: PT. Prenhallindo. 
Lukman, Sampara. 2000. Manajemen Kualitas Pelayanan. Jakarta: STIA LAN press.

Nasir, Muhammad 1995. Metode Penelitian. Jakarta: Ghali Indonesia.

Peraturan Menteri Dalam Negeri NO; 24 Tahun 2006 Tentang Pelayanan Terpadu Satu Pintu

Peraturan Pemerintah No.41 Tahun 2007 Tentang Perangkat Daerah

Rusli, Budiman. 2004. Pelayanan Publik di Era Reformasi. www.pikiran-rakyat.com

Suhartiningsih, 2009. Evaluasi Potensi Pajak Daerah Sebagai Sumber PAD (www.etd.eprints.ums.ac.id, di akses tgl 29 oktober 2011)

Sunindhia,dan Ninik Widianti,1992. Administrasi Negara dan Peradilan Administrasi. Jakarta: PT Rineka Cipta.

Syafie, Inu Kencana. 1999. Ilmu Administrasi Publik. Jakarta: Rineka Cipta

Undang-Undang No. 32 Tahun 2004 Tentang Pemerintah Daerah

Undang-Undang No.33 Tahun 2004 Tentang Perimbangan Keuangan Pusat dan Daerah.

Yahya, I. 2010. Pengertian PAD. (www.repository.usu.ac.id, diakses tgl 29 oktober 2011)

http://kpt-palopo.blogspot.com/ 